\title{
INDIKATOR RAWAT INAP PADA MASA PANDEMI COVID-19 DI RSI ASSYIFA SUKABUMI
}

\author{
Septiani Tri Utami ${ }^{*}$, Vanny Hendriyan Azizah ${ }^{2}$, Sali Setiatin ${ }^{3}$ \\ Politeknik Piksi Ganesha Bandung, Indonesia ${ }^{1,2,3}$ \\ striutami@piksi.ac.id ${ }^{1 *}$, vhendriyan@piksi.ac.id ${ }^{2}$, salisetiatin@gmail.com ${ }^{3}$
}

Received: 17-07-2021

Revised : 08-09-2021

Accepted: 24-09-2021

\begin{abstract}
Abstrak
Latar Belakang: Penyelenggaraan rekam medis yang baik akan menunjang terselenggaranya peningkatan pelayanan kesehatan yang baik dirumah sakit, di masa pandemi COVID-19 pelayanan dirumah sakit terhambat. Sehingga dinilai perlu meyiapkan ruangan dengan kapasitas yang memadai sesuai dengan kebutuhan dimasa kunjungan pasien terkonfirmasi COVID-19. Kasus pertama COVID-19 di Rumah Sakit Islam Assyifa terkonfirmasi Pada bulan April 2020 dan kasusnya meningkat hingga saat ini.
\end{abstract}

Tujuan: Tujuan penelitian dilakukan untuk menganalisis indikator pelayanan rawat inap berdasarkan standar DepKes dan Barber Johnson di Rumah Sakit Islam Assyifa Sukabumi di masa pandemi COVID-19 tahun 2020.

Metode: Jenis penelitian adalah Penelitian Deskriptif dengan Pendekatan Retrosfektif. Populasi yang digunakan adalah data rekapitulasi Sensus Harian Rawat Inap tahun 2020.

Hasil: Hasil penelitian, BOR pada triwulan II dan IV menurun, LOS setiap triwulan sama, TOI meningkat pada triwulan II dan IV, BTO setiap triwulan dibawah angka ideal, GDR NDR setiap triwulan memenuhi standar menurut Depkes. Begitupun pada kasus COVID-19 BOR belum ideal yaitu 39\%, LOS ideal, TOI belum ideal yaitu 10 hari, BTO ideal yaitu 6 kali dan GDR NDR belum ideal yaitu 72\% dan $29 \%$, dapat disimpulkan nilai indikator pada tahun 2020 belum efisien.

Kesimpulan: Kesimpulan dari hasil penelitian yaitu Indikator Rawat Inap di RSI Assyifa Sukabumi belum ideal. Karena, sarana dan prasarana belum terpenuhi. Sehingga harus adanya peningkatan terhadap pelayanan dan perlengkapan yang dibutuhkan untuk kasus COVID-19 tersebut di Rumah Sakit Islam Assyifa Sukabumi.

Kata kunci: indikator rawat inap; pelayanan; COVID-19.

\begin{abstract}
Background: The implementation of good medical records will support the implementation of improving good health services in hospitals, during the COVID-19 pandemic, hospital services are hampered. So it is considered necessary to prepare a room with adequate capacity in accordance with the needs during the visit of confirmed
\end{abstract}


COVID-19 patients. The first case of COVID-19 at the Assyifa Islamic Hospital was confirmed in April 2020 and the cases have increased to date.

Objective: The purpose of the study was to analyze the efficiency of inpatient services based on the standards of the Ministry of Health and Barber Johnson at the Assyifa Islamic Hospital in Sukabumi during the 2020 COVID-19 pandemic.

Methods: The type of research is descriptive research with a retrospective approach. The population used is the 2020 Inpatient Daily Census recapitulation data.

Results: The results of the study, BOR in the second and fourth quarters decreased, the LOS was the same every quarter, TOI increased in the second and fourth quarters, the BTO every quarter was below the ideal number, the GDR NDR every quarter met the standards according to the Ministry of Health. Likewise in the case of COVID-19, BOR is not ideal, namely 39\%, LOS is ideal, TOI is not ideal, which is 10 days, BTO is ideal, which is 6 times and GDR $N D R$ is not yet ideal, namely $72 \%$ and $29 \%$, it can be concluded that the indicator value in 2020 is not efficient.

Conslusion: The conclusion of the research is that the Inpatient Indicator at RSI Assyifa Sukabumi is not ideal. Because, the facilities and infrastructure have not been fulfilled. So there must be an increase in the services and equipment needed for the COVID-19 case at the Assyifa Sukabumi Islamic Hospital.

Keywords: hospitalization indicator; service; COVID-19.

*Coresponden Author: Septiani Tri Utami

*Email : striutami@piksi.ac.id

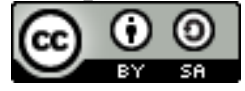

\section{PENDAHULUAN}

Berdasarkan Undang-Undang No. 44 Tahun 2009 tentang rumah sakit, yang dimaksudkan dengan rumah sakit adalah institusi pelayanan kesehatan yang menyelenggarakan pelayanan kesehatan perorangan secara paripurna yang menyediakan pelayanan rawat inap, rawat jalan, dan gawat darurat (Ulum \& Soffi Handayani, 2017). Menurut PERMENKES 269/PER/III/2008 tentang Rekam Medis dalam Pasal 1 ayat (1) Rekam Medis adalah berkas yang berisikan catatan dan dokumen tentang identitas pasien, pemeriksaan, pengobatan, tindakan dan pelayanan lain yang telah diberikan kepada pasien (Permenkes, 2008).

Penyelenggaraan Rekam Medis yang baik akan menunjang terselenggaranya peningkatan pelayanan kesehatan yang baik dirumah sakit, salah satunya adalah Sistem informasi rumah sakit. bagian dalam sistem informasi rumah sakit adalah sistem informasi pelaporan rumah sakit, yang dapat digunakan dalam mengolah data pelaporan rumah sakit (Budi, 2011). Pelaporan yang dilakukan rumah sakit merupakan suatu alat yang bertujuan untuk menghasilkan laporan yang cepat, tepat serta dapat dipercaya guna berbagai keperluan pengelolaan rumah sakit. Dalam menulis pelaporan rumah sakit dengan baik, pengelola perlu memahami statistik rumah sakit sehingga data bisa didapatkan secara benar dan akurat (Novarinda \& Dewi, 2017). 
Statistik rumah sakit yaitu statistik yang menggunakan dan mengolah sumber data dari pelayanan kesehatan di rumah sakit untuk menghasilkan informasi, fakta dan pengetahuan berkaitan dengan pelayanan kesehatan di rumah sakit (Sudra, 2010). Sensus harian rawat inap merupakan kumpulan data pasien yang masuk dan keluar bangsal. Informasi yang diperoleh dari sensus harian rawat inap yaitu berupa data yang akan diolah menjadi sebuah informasi yang dibutuhkan oleh rumah sakit (Hatta, 2010). Efisiensi merupakan salah satu parameter kinerja yang secara teoritis mendasari seluruh kinerja suatu organisasi (Novarinda \& Dewi, 2017).

Indikator-indikator pelayanan rumah sakit dapat dipakai untuk mengetahui tingkat pemanfaatan, mutu dan efisiensi pengelolaan rumah sakit. Beberapa indikator penilaian pelayanan rumah sakit menurut Irwandy (2007), diantaranya adalah sebagai berikut (Hidayah, 2019).

\section{Bed Occupancy Rate (BOR)}

BOR adalah presentase pemakaian tempat tidur pada satuan waktu tertentu. Indikator ini memberikan gambaran tinggi rendahnya tingkat pemanfaatan tempat tidur rumah sakit.

\section{Length Of Stay (LOS)}

LOS adalah rata-rata lama rawat seorang pasien. Indikator ini digunakan untuk mengukur efisiensi pelayanan rawat inap yang tidak dapat dilakukan sendiri, tetapi harus bersama dengan interpretasi BOR dan TOI.

\section{Turn Over Interval (TOI)}

TOI adalah rata-rata hari dimana tempat tidur tidak ditempati dari telah diisi ke saat terisi berikutnya. Indikator ini memberikan gambaran tingkat efisiensi penggunaan tempat tidur. Semakin besar TOI maka efisiensi penggunaan tempat tidur semakin jelek.

\section{Bed Turn Over (BTO)}

BTO adalah frekuensi pemakaian tempat tidur pada satu periode, berapa kali tempat tidur dipakai dalam satu satuan waktu tertentu.

\section{Gross Death Rate (GDR)}

Pada kematian dibedakan kematian secara keseluruhan atau gross death rate. GDR adalah angka kematian umum untuk setiap 1000 penderita keluar rumah sakit (Kemenkes, 2011).

\section{Net Death Rate (NDR)}

NDR yaitu angka kematian 48 jam setelah dirawat untuk tiap-tiap 1000 penderita keluar. Indikator ini memberikan gambaran mutu pelayanan di rumah sakit (Kemenkes, 2011).

Informasi mengenai nilai BOR, LOS, TOI, BTO, GDR, dan NDR tiap periodenya dapat digunakan untuk memperkirakan target efisiensi yang harus dicapai oleh rumah sakit, dan apakah kebijakan yang sudah ada telah efektif atau belum. Perhitungan per bulan dapat membantu mengevaluasi nilai indikator setiap bulanya. Selain itu dapat digunakan untuk mengetahui nilai indikator rawat inap berdasarkan standar Departemen Kesehatan Republik Indonesia (Rosita, 2019).

Grafik Barber Johnson adalah suatu alat penyajian visual yang dapat menyajikan dengan jelas tingkat efisiensi pengelolaan Rumah Sakit (Medis dan ekomoni). Grafik ini ditemukan oleh Barry Barber dan David Johnson pada tahun 1973. Grafik Barber Johnson merupakan suatu indikator yang menggunakan empat parameter menurut (YanMed \& Depkes, 1997) yang terdiri dari :

1. BOR (Bed Ocupanccy Rate), yaitu persentase tempat tidur terisi

2. LOS (Length of Stay), yaitu rata-rata lama dirawat

3. TOI (Turn Over Interval), yaitu rata-rata waktu luang tempat tidur

4. BTO (Bed Turn Over), yaitu produktivitas tempat tidur

Perbandingan kegiatan antar bagian yang sama di beberapa rumah sakit atau antar bagian di suatu rumah sakit dapat digambarkan dengan satu grafik. Dengan jelas dan mudah 
dapat diambil kesimpulan, rumah sakit mana atau bagian mana yang pengelolaan rawat inapnya telah efisien (Sudra, 2010).

Coronavirus Disease 2019 (COVID-19) merupakan penyakit menular yang disebabkan oleh Coronavirus jenis baru. Penyakit ini diawali dengan munculnya kasus pneumonia yang tidak diketahui etiologinya di Wuhan, China pada akhir Desember 2019 (Kementerian Kesehatan RI, 2020).

Pada masa pandemi ini, fasilitas layanan kesehatan pun membatasi layanan kesehatan untuk pasien umum (pasien non COVID-19) agar fokus dalam memberikan layanan keesehatan kepada pasien COVID-19 serta mengurangi risiko penularan di pelayanan kesehatan. Di Indonesia sendiri kasus pertama COVID-19 terkonfirmasi pada tanggal 2 Maret 2020. Kasus pertama COVID-19 di rumah sakit islam assyifa terkonfirmasi Pada bulan April 2020 dan kasusnya meningkat hingga saat ini. Berdasarkan data yang diperoleh dari SHRI Pasien covid-19 di Rumah Sakit Assyifa pada tahun 2020 mencapaii 203 jiwa dengan kasus kematian 17 jiwa.

Untuk mengetahui tingkat pemanfaatan, mutu, efisiensi pelayanan rawat inap dan efisiensi penggunaan tempat tidur di rumah sakit baik untuk pasien covid atau non covid. Maka, diperlukan adanya indikator rawat inap yang terdiri dari BOR (Bed Occupancy Rate), LOS (Length Of Stay), TOI (Turn Over Interval), BTO (Bed Turn Over). Penilaian efisiensi pemanfaatan pelayanan rawat inap dapat dilihat dengan menggambarkan secara cermat Grafik Barber-Johnson dalam menentukan sudut mutu pelayanan medik dan mendayagunakan sarana yang ada dalam segi ekonomis (Putri Lasayka Fidora, 2020)

Berdasarkan latar belakang tersebut, penulis tertarik untuk mengambil judul "Indikator Rawat Inap Pada Masa Pandemi COVID-19 di Rumah Sakit Islam Assyifa Sukabumi". Tujuan dari penelitian ini untuk menganalisis indikator pelayanan rawat inap di RSI Assyifa Sukabumi di masa pandemi tahun 2020. Penelitian ini dilakukan sebagai bahan acuan peningkatan indikator pelayanan rumah sakit ke arah yang lebih efektif dan efisien juga meningkatkan ilmu pengetahuan tentang rekam medis bagi peneliti dan pihak rumah sakit.

\section{METODE PENELITIAN}

Jenis penelitian yang digunakan adalah penelitian deskriptif dengan pendekatan retrosfektif. (Simanjuntak et al., 2019) Penelitian dilakukan pada bulan April sampai Juni 2020. Penelitian dilakukan di Rumah Sakit Islam Assyifa Sukabumi. Populasi dan sample yang digunakan adalah data rekapitulasi SHRI tahun 2020 pengumpulan data dilakukan dengan catatan lapangan dan wawancara. Analisis data dilakukan dengan Statistik Deskriptif yaitu data yang disajikan dalam bentuk tabel distribusi frekuensi sesuai dengan data yang telah terkumpul.

\section{HASIL DAN PEMBAHASAN}

\section{A. Hasil Penelitian}

Tabel 1. Data Rekapitulasi Rawat Inap Tahun 2020 di RSI Assyifa Sukabumi.

\begin{tabular}{lccccc}
\hline \multirow{2}{*}{ Indikator } & \multicolumn{4}{c}{ Triwulan } & \multirow{2}{*}{ COVID-19 } \\
\cline { 2 - 5 } & I & II & III & IV & \\
\hline Hari Perawatan & 9365 & 6810 & 9043 & 5927 & 1428 \\
\hline Lama Dirawat & 9505 & 6744 & 9572 & 6060 & 1289 \\
\hline
\end{tabular}




\begin{tabular}{lccccc}
\hline Px Keluar $(\mathrm{H}+\mathrm{M})$ & 3682 & 2509 & 3729 & 2222 & 236 \\
\hline Px Mati & 46 & 37 & 26 & 52 & 17 \\
\hline Mati < 48 Jam & 29 & 26 & 14 & 24 & 10 \\
\hline Mati > 48 Jam & 17 & 11 & 12 & 16 & 7 \\
\hline TT Siap Pakai & 160 & 160 & 160 & 144 & 41 \\
\hline Periode & 91 & 91 & 92 & 92 & 92 \\
\hline
\end{tabular}

Sumber Referesi data tabel : Data Primer 2020

Berdasrkan tabel 1, Periode pada kasus COVID-19 di cantumkan pada triwulan IV dikarenakan saat itu rumah sakit masih kebingungan untuk pelaporan pasien COVID19.

Tabel 2. Indikator Rawat Inap Tahun 2020 di RSI Assyifa Sukabumi

\begin{tabular}{|c|c|c|c|c|c|c|}
\hline \multirow{2}{*}{ Periode } & \multicolumn{6}{|c|}{ Indikator } \\
\hline & BOR & LOS & TOI & BTO & GDR & NDR \\
\hline Triwulan I & $64 \%$ & 3 Hari & 2 Hari & 23 Kali & $12,5 \%$ & $4,6 \% 0$ \\
\hline Triwulan II & $47 \%$ & 3 Hari & 3 Hari & 16 Kali & $14,7 \%$ & $4,3 \%$ \\
\hline Triwulan III & $62 \%$ & 3 Hari & 2 Hari & 24 Kali & $6,9 \%$ & $3,2 \%$ \\
\hline Triwulan IV & $45 \%$ & 3 Hari & 4 Hari & 16 Kali & $23 \%$ & $7,2 \%$ \\
\hline COVID-19 & $39 \%$ & 6 Hari & 10 Hari & 6 Kali & $72 \%$ & $29 \%$ \\
\hline
\end{tabular}

Sumber Referesi data tabel : Data diolah penulis 2021

Berdasarkan tabel 2, hasil penelitian, BOR pada triwulan II dan IV menurun, LOS setiap triwulan sama, TOI meningkat pada triwulan II dan IV, BTO setiap triwulan dibawah angka ideal, GDR NDR setiap triwulan memenuhi standar menurut Depkes. Begitupun pada kasus COVID-19 BOR belum ideal yaitu 39\%, LOS ideal, TOI belum ideal yaitu 10 hari, BTO ideal yaitu 6 kali dan GDR NDR belum ideal yaitu 72\%o dan 29\%, dapat disimpulakan nilai indikator pada tahun 2020 belum efisien.

Hasil dari data pelaporan pelayanan rawat inap yg diambil dari data rekapitulasi SHRI, kemudian data diolah secara manual untuk menghasilkan indikator BOR, LOS, TOI, BTO, GDR dan NDR. Untuk mengetahui tingkat efisiensi di suatu ruangan rawat inap, perlu adanya suatu indikator untuk mengukur apakah ruangan rawat inap tersebut sudah efisien atau belum. Beberapa indikator efisiensi rawat inap diantaranya :

\section{BOR (Bed Occupancy Rate)}

Lingkup penghitungan BOR ditentukan berdasarkan kebijakan intern rumah sakit, misalnya BOR per ruangan atau BOR seluruh ruangan rawat inap di suatu rumah sakit. Untuk menghitung BOR dapat menggunakan rumus :

\begin{tabular}{|ccc|}
\hline Rumus & hari perawatan & $\mathrm{X}$ \\
\cline { 2 - 2 }$=$ & $\begin{array}{c}\text { Jumlah TT } \mathrm{x} \\
\text { Periode }\end{array}$ & $100 \%$ \\
\hline
\end{tabular}

Berikut Nilai BOR yang dihasil berdasarkan data yang diolah dari SHRI di Rumah sakit Islam Assyifa Sukabumi Tahun 2020 per triwulan dan data COVID-19 secara keseluruhan. 
Tabel 3. Nilai BOR di RSI Assyifa Tahun 2020

\begin{tabular}{llcc}
\hline \multicolumn{1}{c}{ Periode } & BOR & Standar DepKes & Barber Johnson \\
\hline Triwulan I & $64 \%$ & & \\
\cline { 1 - 2 } Triwulan II & $47 \%$ & & \\
\cline { 1 - 2 } Triwulan III & $62 \%$ & $60-85 \%$ & $75-85 \%$ \\
\hline Triwulan IV & $45 \%$ & & \\
\hline COVID-19 & $39 \%$ & & \\
\hline
\end{tabular}

Sumber Referesi data tabel : Data diolah penulis 2021

Berdasarkan tabel 3, dapat diketahui bahwa nilai BOR pada triwulan I dan III memenuhi standar depkes sedangkan pada triwulan II dan IV angkanya menurun. Begitupun pada kasus COVID-19 nilainya tidak memenuhi standar DepKes maupun Barber Johnson hal ini dikarenakan masi sedikitnya pasien COVID-19 yang menggunakan fasilitas perawatan di RSI Assyifa Sukabumi sedangkan saat ini pasien COVID-19 semakin meningkat. Kemungkinan nilai BOR akan naik bahkan sampai melebihi nilai standar.

\section{LOS ( Length of Stay)}

Indikator LOS memberikan gambaran tingkat efisiensi juga dapat memberikan gambaran mutu pelayanan. Untuk menghitung LOS dapat menggunakan rumus :

Rumus LOS $=\frac{\text { Jumlah lama dirawat }}{\text { Jumlah pasien keluar }(\mathrm{H}+\mathrm{M})}$

Berikut Nilai LOS yang dihasil berdasarkan data yang diolah dari SHRI di Rumah sakit Islam Assyifa Tahun 2020 per triwulan dan data COVID-19 secara keseluruhan.

Tabel 4. Nilai LOS di RSI Assyifa Tahun 2020

\begin{tabular}{|c|c|c|c|}
\hline Periode & LOS & Standar DepKes & Barber Johnson \\
\hline Triwulan I & 3 Hari & \multirow{5}{*}{ 6-9 hari } & \multirow{5}{*}{ 3-12 hari } \\
\hline Triwulan II & 3 Hari & & \\
\hline Triwulan III & 3 Hari & & \\
\hline Triwulan IV & 3 Hari & & \\
\hline COVID-19 & 6 Hari & & \\
\hline
\end{tabular}
Sumber Referesi data tabel : Data diolah penulis 2021

Berdasarkan tabel 4, dapat diketahui bahwa nilai LOS setiap triwulannya memenuhi standar DepKes maupun standar Barber Johnson begitupun nilai LOS pada kasus COVID-19. hal ini dapat diartikan mutu pelayanan di RSI Assyifa sudah baik, sehingga pasien tidak memerlukan waktu yang lama ketika dirawat.

\section{TOI (Turn Over Interval)}

perhitungan nilai TOI ditentukan berdasarkan seberapa efektifnya pelayanan di rumah sakit. Untuk menghitung nilai TOI bisa digunakan rumus :

Rumus TOI $=\frac{\text { (Jumlah tempat tidur X Periode) }- \text { Hari perawatan }}{\text { Jumlah pasien keluar }(\mathrm{H}+\mathrm{M})}$

Berikut Nilai TOI yang dihasil berdasarkan data yang diolah dari SHRI di RSI Assyifa Tahun 2020 per triwulan dan data COVID-19 secara keseluruhan. 
Tabel 5. Nilai TOI di RSI Assyifa Tahun 2020

\begin{tabular}{|c|c|c|c|}
\hline Periode & TOI & Standar Depkes & Barber Johnson \\
\hline Triwulan I & 2 Hari & \multirow{5}{*}{ 1-3 hari } & \multirow{5}{*}{ 1-3 hari } \\
\hline Triwulan II & 3 Hari & & \\
\hline Triwulan III & 2 Hari & & \\
\hline Triwulan IV & 4 Hari & & \\
\hline COVID-19 & 10 Hari & & \\
\hline
\end{tabular}

Sumber Referesi data tabel : Data diolah penulis 2021

Berdasarkan tabel 5, dapat diketahui bahwa nilai TOI pada setiap triwulan memenuhi standar DepKes maupun standar Barber Johnson kecuali triwulan IV mengalami peningkatan sehingga tidak memenuhi standar, begitupun pada kasus COVID19 nilainya sangat tinggi melebihi standar. Hal ini dapat diartikan semakin besar nilai TOI semakin lama TT tidak terisi atau digunakan oleh pasien. terutama pada kasus COVID-19 karena masih sedikitnya pasien pada tahun tersebut.

\section{BTO (Bed Turn Over)}

Perhitungan nilai BTO ditentukan berdasarkan seberapa banyak pasien dirawat dan jumlah TT. Untuk menghitung BTO menggunakan rumus sebagai berikut :

Rumus BTO $=\frac{\text { Jumlah pasien keluar }(\mathrm{H}+\mathrm{M})}{\text { Jumlah tempat tidur }}$

Berikut Nilai BTO yang dihasil berdasarkan data yang diolah dari SHRI di RSI Assyifa Tahun 2020 per triwulan dan data COVID-19 secara keseluruhan.

Tabel 6. Nilai BTO di RSI Assyifa Tahun 2020

\begin{tabular}{|c|c|c|c|}
\hline Periode & BTO & Standar DepKes & Barber Johnson \\
\hline Triwulan I & 23 kali & \multirow{5}{*}{ 40-50 kali } & \multirow{5}{*}{30 kali } \\
\hline Triwulan II & 16 kali & & \\
\hline Triwulan III & 24 kali & & \\
\hline Triwulan IV & 16 kali & & \\
\hline COVID-19 & 6 kali & & \\
\hline
\end{tabular}

Sumber Referesi data tabel : Data diolah oleh penulis 2021

Berdasarkan tabel 6, dapat diketahui bahwa nilai BTO pada setiap triwulan dan pada kasus COVID-19 sudah sesuai dengan standar yaitu 40-50 kali dalam setahun menurut DepKes, hal ini dapat diartikan banyaknya persediaan tempat tidur dirumah sakit.

\section{GDR (Gross Death Rate)}

GDR adalah angka kematian umum untuk setiap 1000 penderita keluar rumah sakit . (Kementerian Kesehatan, 2011). Untuk menghitung GDR menggunakan rumus sebagai berikut :

$$
\text { Rumus GDR }=\frac{\text { Jumlah pasien mati seluruhnya }}{\text { Jumlah pasien keluar }(\mathrm{H}+\mathrm{M})} \quad \begin{gathered}
\mathrm{X} \\
1000 \%
\end{gathered}
$$


Berikut Nilai GDR yang dihasil berdasarkan data yang diolah dari SHRI di RSI Assyifa Tahun 2020 per triwulan dan data covid secara keseluruhan.

Tabel 7. Nilai GDR di RSI Assyifa Tahun 2020

\begin{tabular}{ccc}
\hline Periode & GDR & Standar DepKes \\
\hline Triwulan I & $12,5 \% 0$ & $<45 \%$ \\
\hline Triwulan II & $14,7 \% 0$ & \\
\hline Triwulan III & $6,9 \% 0$ & \\
\hline Triwulan IV & $23 \% 0$ & \\
\hline COVID-19 & $72 \% 0$ &
\end{tabular}

Sumber Referesi data tabel : Data diolah penulis 2021

Berdasarkan tabel 7, dapat diketahui bahwa nilai GDR pada setiap triwulan memenuhi standar menurut DepKes karena angka GDR kurang dari 45\%o sedangkan pada kasus COVID-19 angka GDR melebihi standar hal ini dikarenakan COVID-19 merupakan penyakit jenis baru sehingga kinerja pelayanan petugas masi belum sesuai.

\section{NDR (Net Death Rate)}

Indikator ini memberikan gambaran mutu pelayanan di rumah sakit. Untuk menghitung NDR menggunakan rumus sebagai berikut :

\begin{tabular}{|c|c|c|}
\hline & Jumlah pasien mati >48jam & $\mathrm{x}$ \\
\hline & Jumlah pasien keluar (H+M) & $1000 \%$ \\
\hline
\end{tabular}

Berikut Nilai NDR yang dihasil berdasarkan data yang diolah dari SHRI di RSI Assyifa Tahun 2020 per triwulan dan data covid secara keseluruhan.

Tabel 8. Nilai NDR di RSI Assyifa Tahun 2020

\begin{tabular}{ccc}
\hline Periode & NDR & Standar DepKes \\
\hline Triwulan I & $4,6 \%$ o & \\
\hline Triwulan II & $4,3 \% 0$ & \\
\hline Triwulan III & $3,2 \% 0$ & $<25 \% 0$ \\
\hline Triwulan IV & $7,2 \% 0$ & \\
\hline COVID-19 & $29 \%$ & \\
\hline
\end{tabular}

Sumber Referesi data tabel: Data diolah penulis 2021

Berdasarkan tabel 8, dapat diketahui bahwa nilai NDR pada setiap triwulan memenuhi standar menurut DepKes karena angka GDR kurang dari 25\% sedangkan pada kasus COVID-19 angka NDR melebihi standar hal ini dikarenakan COVID-19 merupakan penyakit jenis baru sehingga kinerja pelayanan petugas masih belum sesuai.

\section{Grafik Barber Johnson}

Grafik Barber Johnson di buat dari hasil perhitungan BOR, LOS, TOI dan BTO. Berikut adalah grafik Barber Johnson per Triwulan tahun 2020 di RSI Assyifa dan juga grafik Barber Johnson COVID-19. 


\section{Grafik Triwulan I}

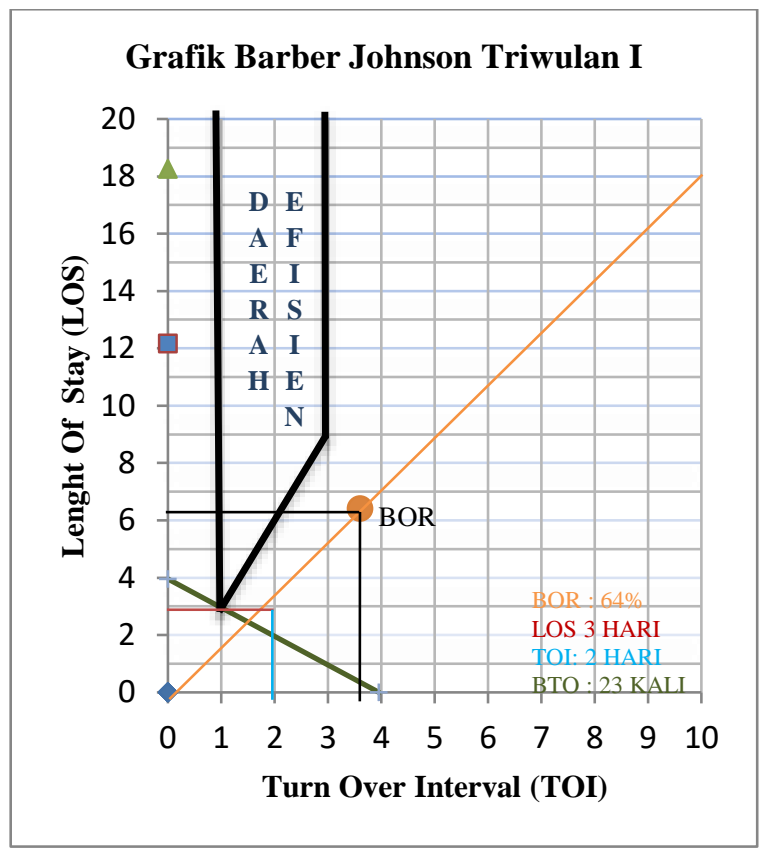

Grafik 1. Data diolah penulis 2021

Berdasarkan grafik pada triwulan 1 pertemuan titik ke empat indikator dalam grafik tidak berada dalam daerah efisien menurut grafik Barber Johnson. Nilai LOS berada pada titik 3 pada sumbu Y, nilai TOI berada pada titik 2 pada sumbu X, nilai BOR beada pada titik garis $64 \%$ dan nilai BTO berada pada titik 23 .

\section{Grafik Triwulan II}

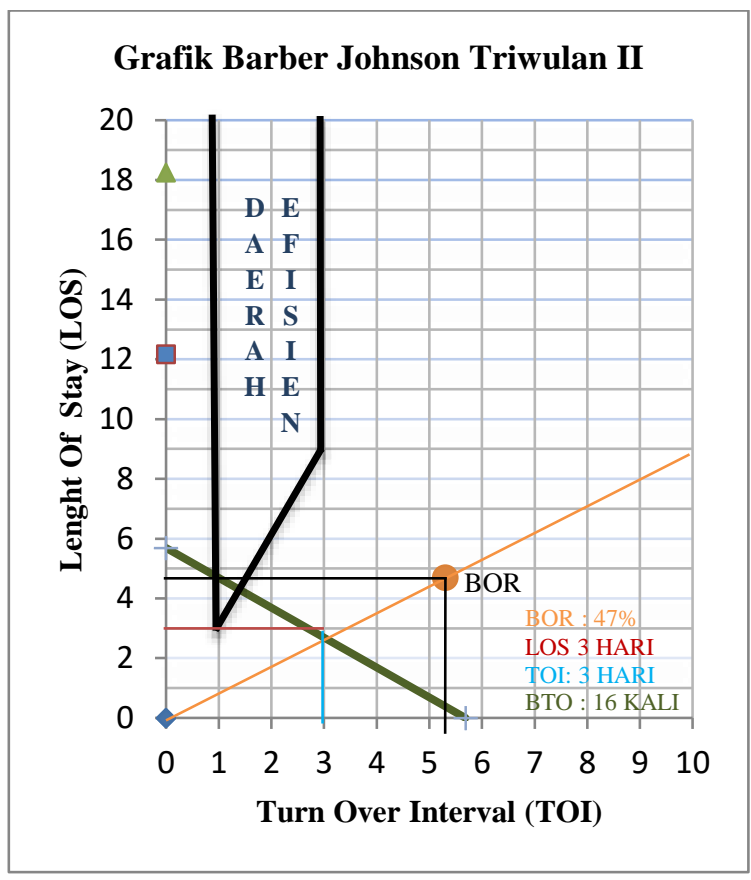

Grafik 2. Data diolah penulis 2021 
Berdasarkan grafik pada triwulan II pertemuan titik ke empat indikator dalam grafik tidak berada dalam daerah efisien menurut grafik Barber Johnson. Nilai LOS berada pada titik 3 pada sumbu Y, nilai TOI berada pada titik 1 pada sumbu X, nilai BOR beada pada titik garis 47\% dan nilai BTO berada pada titik 16.

\section{Grafik Triwulan III}

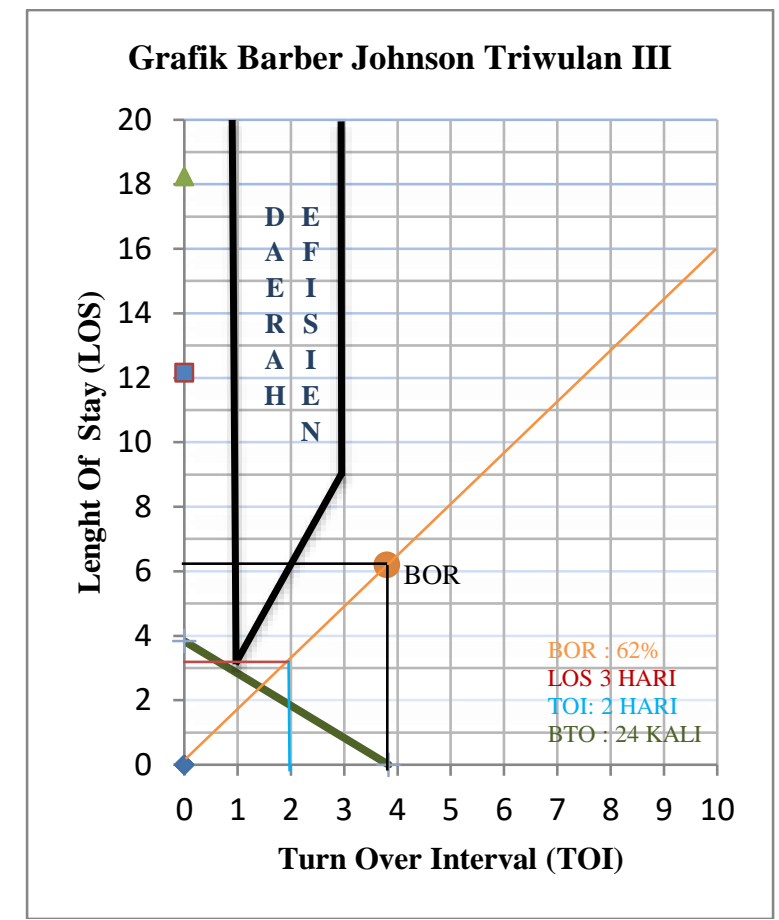

Grafik 3. Data diolah penulis 2021

Berdasarkan grafik pada triwulan III pertemuan titik ke empat indikator dalam grafik tidak berada dalam daerah efisien menurut grafik Barber Johnson. Nilai LOS berada pada titik 3 pada sumbu Y, nilai TOI berada pada titik 2 pada sumbu X, nilai BOR beada pada titik garis $62 \%$ dan nilai BTO berada pada titik 24 . 


\section{Grafik Triwulan IV}

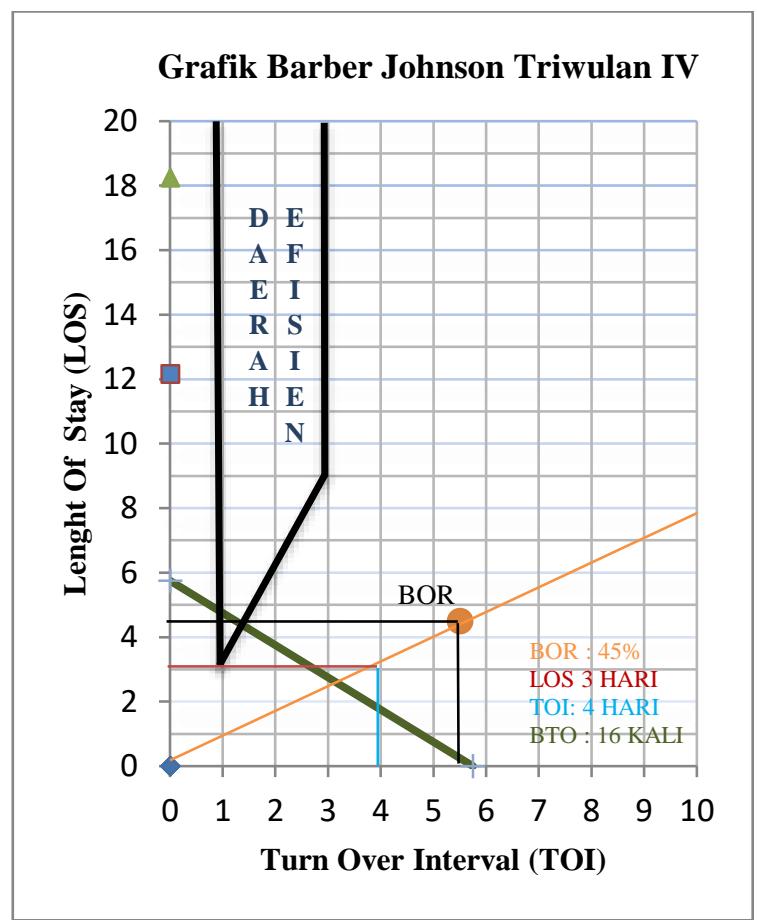

Grafik 4. Data diolah penulis 2021

Berdasarkan grafik pada triwulan IV pertemuan titik ke empat indikator dalam grafik tidak berada dalam daerah efisien menurut grafik Barber Johnson. Nilai LOS berada pada titik 3 pada sumbu Y, nilai TOI berada pada titik 4 pada sumbu X, nilai BOR beada pada titik garis $45 \%$ dan nilai BTO berada pada titik 16 .

\section{Grafik COVID-19}

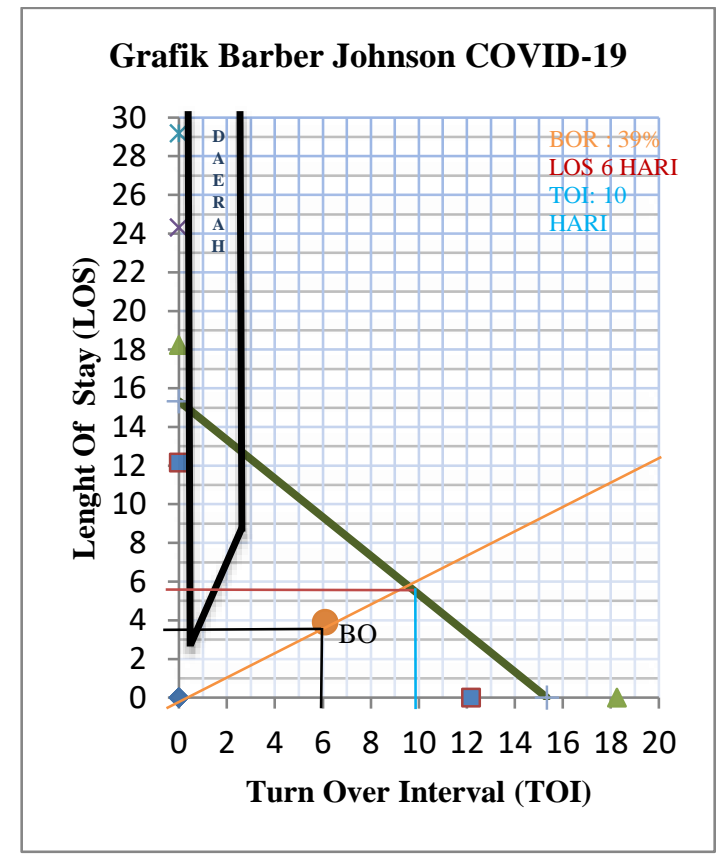

Grafik 5. Data diolah penulis 2021 
Berdasarkan grafik COVID-19 pertemuan titik ke empat indikator dalam grafik tidak berada dalam daerah efisien menurut grafik Barber Johnson. Nilai LOS berada pada titik 6 pada sumbu Y, nilai TOI berada pada titik 10 pada sumbu X, nilai BOR beada pada titik garis 39\% dan nilai BTO berada pada titik 6 .

\section{B. Pembahasan}

Menurut RSI Assyifa ( 2021) Kasus pertama COVID-19 terkonfirmasi Pada bulan April 2020 dan kasusnya meningkat hingga saat ini, gejala umum yang terjadi saat terinfeksi COVID-19 antara lain gejala gangguan pernapasan akut seperti demam, batuk dan sesak napas. Data pasien COVID-19 di Indonesia hingga tanggal 22 juni 2021 mencapai 2.014.536 dengan kasus kematian mencapai 55.250 jiwa. Berdasarkan data yang diperoleh dari SHRI Pasien COVID-19 di Rumah Sakit Assyifa pada tahun 2020 mencapaii 203 jiwa dengan kasus kematian 17 jiwa. Sumber data kunjungan rawat inap di peroleh dari sensus harian rawat inap (SHRI) yang dilakukan setiap hari pada setiap ruang rawat inap.

Hasil penelitian terdahulu oleh Mardiyono (2011) Penilaian dari triwulan I sampai triwulan IV tahun 2011 menurut Grafik Barber Johnson efisiensi pelayanan rawat inap mengalami kecondongan untuk masuk didaerah efisiensi, untuk itu dapat terlihat di triwulan III, keempat indikator keberadaannya diluar daerah efisiensi seelain itu pada triwulan IV dari keempat indikator keberadaannya masuk didaerah efisiensi.

Bersumber dari penelitian Nursamda (2017), Hal yang memengaruhi efisiensi layanan rawat inap yaitu kurang memadainya sarana dan prasarana terutama pemeriksaan penunjang medik, keterbatasan ruangan untuk penambahan tempat tidur, minimnya promosi khusus dari bagian rawat inap, serta banyaknya rumah sakit pesaing yang memiliki sarana dan prasarana penunjang (Hijrah, 2017).

Berdasarkan hasil penelitian, nilai BOR pada triwulan II dan IV menurun dibandingkan pada triwulan I dan III , LOS setiap triwulan sama, TOI meningkat pada triwulan II dan IV, BTO setiap triwulan dibawah angka ideal, GDR NDR setiap triwulan memenuhi standar menurut DepKes. Begitupun pada kasus COVID-19 BOR belum ideal yaitu 39\%, LOS ideal, TOI belum ideal yaitu 10 hari, BTO ideal yaitu 6 kali dan GDR NDR belum ideal yaitu $72 \%$ dan $29 \%$, dapat disimpulakan nilai indikator pada tahun 2020 belum efisien. Maka hal ini dapat menyebabkan kurang efisiennya pemanfaatan tempat tidur, meningkatnya kejadian infeksi nosokomial, beban kerja petugas pelayanan semakin berat maka dari itu untuk memperbaiki perlu di adakan perekrutan dokter dan perelokasian tempat tidur supaya titik pertemuan empat parameter bangsal dapat memasuki daerah efisiensi serta pelayanan kepada pasien dapat maksimal.

\section{KESIMPULAN}

Berdasarkan hasil penelitian dan perhitungan penulis mengenai indikator rawat inap yang digambarkan dengan tabel dan grafik didapatkan hasil BOR, LOS, TOI, BTO, NDR dan GDR 2020 belum ideal. Nilai BOR tertinggi adalah pada triwulan I yaitu sebesar 64\%, nilai BOR terendah yaitu pada triwulan IV dan pada masa pandemic COVID-19. Pada triwulan IV yaitu $45 \%$ dan pada masa pandemic COVID-19 yaitu 39\%. Nilai LOS tertinggi yaitu pada masa pandemi COVID-19 yaitu 6 hari dan nilai LOS pada triwulan I - triwulan IV yaitu 3 hari. Nilai TOI pada triwulan I dan triwulan II sudah ideal yaitu 2-3 hari. Tetapi pada triwulan IV dan dimasa pandemi mengalami peningkatan yaitu 4 dan 10 hari. Nilai BTO tertinggi pada triwulan III yaitu 24 kali dan nilai BTO terendah pada masa pandemi yaitu 6 kali. Nilai GDR pada triwulan I - triwulan IV sudah ideal yaitu $<45 \%$. Tetapi, pada 
masa pandemi nilai GDR naik menjadi $74 \%$. Nilai NDR pada triwulan I - triwulan IV sudah ideal yaitu $<25 \%$. Tetapi, pada masa pandemi nilai NDR naik menjadi $29 \%$. Tingkat efisiensi pengelolaan tempat tidur di RSI Assyifa Sukabumi tahun 2020 termasuk pada kasus COVID-19 berdasarkan standar DepKes maupun Barber Johnson belum sepenuhnya efisien.

\section{BIBLIOGRAFI}

Budi, S. C. (2011). Manajemen unit kerja rekam medis. Yogyakarta: Quantum Sinergis Media.

Hatta, G. (2010). Pedoman Manajemen Informasi Kesehatan di Sarana Pelayanan Kesehatan. UI-Press.

Hidayah, A. E. P. N. (2019). Indikator Statistik Rumah Sakit (BOR, LOS, BTO, TOI). In 7 Mei 2019.

Hijrah, N. (2017). Analisis Efisiensi Pelayanan Rawat Inap Rumah Sakit Bhayangkara Padang Berdasarkan Grafik Barber Johson Tahun 2014-2016. Universtas Andalas.

KemenKes, R. I. (2011). Keputusan Menteri Kesehatan Republik Indonesia tentang Standar Antropometri Penilaian Gizi Anak. Jakarta, Direktorat jenderal Bini Gizi dan Kesehatan Ibu dan Anak.

Kementerian Kesehatan RI. (2020). Pedoman Pencegahan dan Pengendalian Corona Virus deases (Covid-19). Kementrian Kesehatan, 5, 178.

Novarinda, I., \& Dewi, D. R. (2017). Efisiensi Pengelolaan Di Bangsal Asoka Berdasarkan Grafik Barber Johnson Di Rumah Sakit Sumber Waras Triwulan I-IV Tahun 2016. Inohim, 5(1), 14-21.

Permenkes, R. I. (2008). No 269/Menkes/Per/III/2008 tentang Rekam Medis. Jakarta: Menteri Kesehatan Reupublik Indonesia.

Putri Lasayka Fidora. (2020). Analisis Efisiensi Pelayanan Rawat Inap Menurut Grafik Barber-Johnson di RSUD Tanjung Pura Kabupaten Langkat Tahun 2019. Skripsi.

Ramadani, N., Ullatifa, N., \& Yul, F. A. (2020). Sistem Informasi Indikator Pelayanan Rumah Sakit. Junral Edik Informatika, 7(1), 9-18.

Rosita, R., \& Tanastasya, A. R. (2019). Penetapan Mutu Rumah Sakit Berdasarkan Indikator Rawat Inap. Jurnal Kesehatan Kusuma Husada, 166-178. https://doi.org/10.34035/jk.v10i2.392

Simanjuntak, E., S, C. A., Prodi, D., Dan, D. P., Imelda, I., Bilal, J., Medan, N., Perekam, A. D., \& Imelda, D. I. (2019). Analisa Indikator Rawat Inap Periode Tahun. 2, 614 619.

Sudra, R. I. (2010). Statistik Rumah Sakit. In Graha Ilmu (Vol. 1). Garaha Bulan.

Ulum, M., \& Soffi Handayani. (2017). Analisis Efisiensi Rumah Sakit Berdasarkan Grafik Barber Jhonson. Jurnal Kesehatan Vokasional, 4(2), 13-20.

YanMed, D., \& Depkes, R. I. (1997). Pedoman Pengelolaan Rekam Medis Rumah Sakit di Indonesia. DepKes RI, Jakarta.

(C) 2021 by the authors. Submitted for possible open access publication under the

license (https://creativecommons.org/licenses/by-sa/4.0/). 